\title{
UNDERSTANDING THE SUSTAINABILITY STANCE OF MICRO AND SMALL-SIZED ACCOMMODATION OWNER-MANAGERS TO ENTER INTO (SUSTAINABLE) ENTREPRENEURSHIP
}

\author{
FEMKE A. VRENEGOOR ${ }^{1,2}$, GJALT DE JONG ${ }^{2}$ \& ELENA CAVAGNARO ${ }^{1}$ \\ ${ }^{1}$ Academy of International Hospitality Research, NHL Stenden University, The Netherlands \\ ${ }^{2}$ Centre for Sustainable Entrepreneurship University of Groningen/Campus Fryslân, The Netherlands
}

\begin{abstract}
This research looks at the motivates and values of owner-managers of micro and small-sized accommodations for entering into the accommodation business and implementing CSR measures in it. According to theory, it may either be because of self-enhancement motives, for self-transcendent motives, or a combination of the two. These different motives may lead to the entrepreneur implementing sustainability measures in his operations, only the extent and depth to which this is done depends on the underlying values of the person. Explorative semi-structured interviews with the owner-managers of micro and small-sized accommodations were carried out. Results show that indeed the primary reason for entrepreneurs to enter into business is for self-enhancement reasons. Notwithstanding, a number of entrepreneurs mention both self-enhancement and self-transcendence motives. Most entrepreneurs do not mention sustainability as part of their business goal, but have implemented several CSR measures. This goes from basic actions like LED lights and separating waste, until solar panels and waste prevention. When referring to sustainability, the entrepreneurs mostly explain it as actions that are good for the environment. Actions that are good for society are not seen as belonging to sustainability, even though the entrepreneur undertakes several actions that add value to it. Further research is needed to get a better understanding of the types of CSR measures that are implemented in their accommodations, and how this connects to the dominant values of the individual. Keywords: tourism entrepreneurs, accommodation owner-managers, sustainability stance, motives, values, CSR measures, SME's.
\end{abstract}

\section{INTRODUCTION}

The aim of the research presented in this paper is to develop a deeper understanding of the motives of micro and small-sized accommodation owner-managers to enter into business, their sustainability stance and their dominant values. Value theory is used to explain whether patterns in behaviour can be identified. This research thus contributes to the limited research on the intersection between tourism SME's, sustainability and values. This is important, as the tourism industry is seen as having a responsibility to behave morally and ethically [1] and values are ultimate antecedents of pro-environmental behaviour [2]. Values have been shown to decide the business operations for some owner-managers in tourism [3], though little is known about their motives to behave sustainable and the CSR measures they implement [4], especially for SME's [5].

For future generations to be able to have the same quality of life as we currently have in the Western world, it is necessary to take global environmental and social action. The United Nations (UN) created a set of 17 Sustainable Development Goals (SDGs) to end poverty, protect the planet and ensure prosperity for all [6]. A clear role for companies is shown in the SDGs, asking for production of goods and services in a responsible manner, thus "doing more and better with less" [6]. This is necessary, as companies are seen by many to be the most important protagonists of the current unsustainable state of society [7], [8]. 
Globally, the tourism industry is an important contributor to the economy and has seen steady growth over the last few years. In 2017, tourism growth was higher than that of the global economy [9]. In the European Union, it contributes 10\% to its GDP and provides direct and indirect jobs for 26 million persons [10]. In the Netherlands, the direct contribution of tourism to the GDP was $4,4 \%$ in 2018 , and $6,3 \%$ of all jobs were in tourism [11]. According to UNWTO [10], 33\% of all tourism establishments are hotels and similar accommodations and in the Netherlands $95 \%$ of accommodations fall in the micro (less than 10 rooms) and small (less than 50 rooms) size category [12].

Small firms play a key role in the sector [5], [10], but are seen to be lagging behind in their implementation to reduce their negative impact to climate change as to reach the SDGs. As Thomas et al. put forward, SMEs in tourism "have largely failed to embrace the growing environmental agendas of the public sector" [5, p. 969]. Current tourism development is unsustainable [13], and is responsible for approximately $5 \%$ of global $\mathrm{CO}_{2}$ exhaust [13]. Within the tourism industry, accommodations are responsible for $21 \%$ of the impact on climate change [13], and in the Netherlands they are even responsible for about $30 \%$ of the $\mathrm{CO}_{2}$ exhaustion of tourism [14].

To be sustainable, an organization should "manage its resources in such a way that economic, social and environmental benefits are maximized in order to meet the need of the present while protecting and enhancing opportunities for future generations" [15, p. 4]. One way for an organization to take care of this, is by implementing Corporate Social Responsibility (CSR) principles in their company. CSR is defined as the active and voluntary contribution of an enterprise to environmental, social and economic improvement [16], and is concerned with a company's obligations to be accountable to all its stakeholders when operating and undertaking business activities [15]. When speaking about CSR in this paper, all the company's sustainability efforts are meant. The focus of CSR research has been particularly on larger companies. SMEs have received little attention [4], [17]. It is the ownermanager in such accommodations that shapes the organisations strategy [18], and existing research has "failed to understand the reasons behind the possible cognitive constraints that can affect the sustainable orientations of decision-making by SME hotel entrepreneurs" $[19$, p. 146].

There is an ongoing debate about whether the owner-managers of tourism SME's may be called entrepreneurs or not. It is not a goal of this paper to go into this matter. The term entrepreneurs will be used for the owner-managers, as according to Drucker [20] entrepreneurship is a form of behaviour. In academic literature some attention has been given to the antecedents of this behaviour, i.e. individual hotel entrepreneurship. Especially the motives, attitudes and business challenges of such entrepreneurs have been investigated [17]. Though attitudes are one of the factors that decide behaviour [2], literature shows that there is a gap between attitude and behaviour [2]. Values are considered to be stable and ultimate antecedents of behaviour, and might therefore predict not contemporaneous and future choices [2]. They are defined as "desirable trans-situational goals varying in importance, which serve as guiding principles in the life of a person or society" [21, p. 21]. Values guide pro-environmental behaviour such as energy reduction [2], and help to understand why a person will take certain sustainable actions, but will not take others. Limited attention has been given to values as an antecedent of accommodation entrepreneurship, though they are the ultimate antecedent of behaviour, whereas motivations are immediate antecedents [2].

Hence, it makes a lot of sense to study motives and values together. For this research, particularly the values the individual holds as well as their motives to operate a hotel are interesting, because the dominant values, type of motives and the strength they have determine the goals the individual has for their business [17]. Operating in a sustainable 
manner may be one such a business goal. Therefore, we present the findings of our research amongst the owner-managers of micro and small-sized accommodations in the Netherlands. We asked them about their motives to become an entrepreneur, their value orientations and the CSR measures implemented by them and hope to thus help close these knowledge gaps.

\section{THEORETICAL UNDERPINNING}

Thanks to different streams of entrepreneurship literature, we know why some individuals implement CSR in their companies, and others do not. This section will first define traditional entrepreneurship before going into lifestyle entrepreneurship. After, the role of values will be explained in relation to motives to become an entrepreneur to understand from which value orientation that behaviour stems.

Entrepreneurship, in the Schumpeterian sense of the concept, refers to "creative destruction", as it seeks to replace existing products or services in the market place with a superior one [22]. The ability to innovate, to create a new product or service and introduce it successfully to the market place to grow one's business, is seen as a distinguishing feature for entrepreneurs [8]. Opportunity recognition, innovation and risk taking are seen as essential [7], [8]. The afore mentioned definition finds its basis in economic studies, and following it, the owner-managers of micro and small-sized tourism firms would not be considered entrepreneurs due to their lack of having economic goals. Yet, tourism research repeatedly speaks about tourism entrepreneurs, regardless of the size of the organization. This may be explained by considering the specific context of this sector. As Skokic and Morrison put it "this [economic] perspective has failed to explain the motivation of numerous small businesses in tourism which defy models of economic rationality, that of lifestyle entrepreneurs" [23, p. 157]. Lifestyle entrepreneurs are identified as those entrepreneurs who own and operate a business closely aligned with their personal values, beliefs, interests and passions [8], [30]. For them, success of their organization is not expressed in economic terms, but rather in their continued ability to maintain their chosen lifestyle [24]. This puts them at the other end of the renowned continuum across from for-profit/commercial entrepreneurs. However, lifestyle entrepreneurship is still a rather fuzzy concept, and there is some indication that there are more nuances in the motives for entrepreneurship [3], [5], [25].

Besides lifestyle entrepreneurs, another relatively new type of entrepreneur has been identified in literature, namely the sustainable entrepreneur. Such individuals use the opportunity arising from a certain market failure (in this case the unsustainability of the world) as a specific organisational goal to reach value creation on the triple bottom line of people, planet and profit [7], [8]. Here there is an explicit addition of creating social and environmental value, thus this type of entrepreneurs is motivated by self-enhancement values and self-transcendent values. One such an example in the hospitality industry is the Feldmilla hotel in Italy. This is a small family run enterprise which is fully climate neutral and their business goals are connected to society and the environment. However, it remains unclear if all lifestyle entrepreneurs also pursue sustainability goals, such as the Feldmilla hotel.

What is clear, is that next to profit, socioeconomic and environmental values play a role in the decision-making process of at least lifestyle entrepreneurs in tourism [3], and that "applying psychological and sociological lenses" has value when trying to understand the behaviour of individuals commercially letting out accommodation [5, p. 966]. Font et al. [4] offer insight into the implementation of CSR measures by SME tourism business by identifying three frames for engaging in them; cost-reduction competitiveness (taking measures that lead to operational and internal benefit), societal legitimization (taking measures that are visible or expected by others) and lifestyle-value drivers (taking measures due to personal choices and out of habit). It may even be argued that operating one's 
organisation in a sustainable manner may be an outcome of effectuation, rather than a purposeful goal [26]. However, the causation and effectuation theory seems to be largely ignored in tourism and lifestyle research.

It is evident that not all entrepreneurs behave equally sustainable, and that they have different motives to engage in the implementation of CSR measures, if they do so at all. It is necessary to investigate this further due to the considerable $\mathrm{CO}_{2}$ exhaust caused by accommodations, and the large percentage of SME's in the sector. If all these accommodations were to become more sustainable, this would be a significant improvement of the sustainability stance of the tourism industry.

Environmental psychology, social-psychological theory and cognitive theory offer answers to understanding these different sustainability stances by looking at pro-environmental behaviour, and the underlying values guiding such behaviour. Many definitions of pro-environmental behaviour exist, but in this research, it is understood as behaviour that adds value to humans and the environment. Humans are part of the environment and that acting pro-environmentally therefore equals actin pro-socially. Values are a person's guiding principles to reach a desirable trans-situational goal in life [21]. Since they guide life goals, they guide attitude and behaviour to reach that life goal. Therefore, they are important to consider when discussing pro-environmental behaviour. Schwartz' theory reflects that every person holds a number of values at the same time, and the relative importance give to those values differ per person and per circumstance. Values are not about specific action, but rather exceed them, and thus serve as an individual's standards based on which (s)he assesses what is right or wrong, what should be done or not done, and so on. Since each person holds different values, that may be in conflict with each other, a trade off occurs between competing values. Similar values are referred to as value types, and clusters of compatible value types are called value orientations [2].

Values relevant to pro-environmental behaviour can be split in two categories, namely self-enhancement values and self-transcendence values. The first category concerns the overarching value orientation as valuing power, achievement and hedonism, and the second category concern the overarching value orientation for universalism and benevolence [21]. Theoretically, a person with dominant self-enhancement values may perform as pro-environmentally, as persons with dominant altruistic and biospheric values, if those actions align with their self-interest. However, individuals with strong self-transcendence (i.e. altruistic and biospheric) values are more likely to show more salient pro-environmental behaviour [2]. Notwithstanding, it has been shown that general beliefs in support of sustainability, intentions and behaviour are positively connected to biospheric values, and that they are negatively connected to egoistic values [2].

The entrepreneurial behaviour to grow one's business can be seen as behaviour according to self-enhancement values [21], connected to an egoistic value orientation [2]. Becoming an entrepreneur because of the freedom it allows oneself, and because of the status it gives fall under the above explanation. Becoming an entrepreneur to be able to provide for your family, or to help better the economy in one's area are at least partially motivated by altruistic (thus self-transcendence) values. Research using cognitive theory to understand the motives for entrepreneurs in the accommodation industry to enter into business describe various reasons. Some of the most important ones are financial motives, personal satisfaction, independence/working for oneself, and fulfilling a desire to open a hotel [17], [18]. All of these motives fit the definition of self-enhancement values, despite the often-conscious rejection of economic and business growth opportunities in favour of maintaining a certain lifestyle [3]. 
Entrepreneurs with high hedonic and gain values thus have a lower propensity to implement sustainability measures that require effort. This may form a barrier to more stringent implementation of sustainability in accommodations. This barrier is aggravated further by the nature of hospitality: a hotelier's role is to provide the luxury, comfort and service quality that a guest is seeking. These entrepreneurs do not want to hinder guests in their organisations with striving for more sustainable operations [33], even though guests themselves appreciate the green efforts of a hotel [28]. One could say that the aforementioned reflects a cognitive dissonance in accommodation entrepreneurs, where on the one hand they wish to add value to sustainability via their operations, but on the other hand do not want to decrease the guests' experience during their stay.

Values are ultimate antecedent of behaviour, motivations immediate antecedents. A better understanding of the motivation of an entrepreneur to operate an accommodation, the CSR measures they implement and their dominant values will allow to better comprehend their sustainability stance. For this reason, the next section explains how this data was collected.

\section{METHOD}

To collect data, explorative face to face semi-structured interviews were completed. This qualitative approach was chosen because it allows to openly examine the experiences of entrepreneurs, the meaning they give to their business and the choices they make. To avoid socially desirable answers, the respondents were not informed about the overall goal of this research as not to frame them towards sustainability. Rather, the hotelier was asked for their motives to become an entrepreneur in the accommodation industry. This allowed to see if the respondent comes up with sustainability as a motive for operating their business themselves, or only after explicitly being asked for it. This is necessary, as it gives an indication of the prioritized values of the hotelier. To support this goal, a value card game with the 16 values significant for pro-environmental behaviour, as determined by Schwartz [21] and Steg et al. [27] was used. One additional universal value was added to this card game, as entrepreneurship theory shows it is of major importance, namely freedom. In total, the card game contained 17 value cards. During the interview, the owner-manager was asked to select the 5 values that (s)he finds most important, and to rank them hierarchal from most important to least important. A picture of this ranking was taken for analysis purposed, and the five selected cards were used for further discussion with the following interview questions.

A combination of convenience and purposive sampling was used to collect the data. This was done as entrepreneurs in any case are a hard-to-reach group, and even more so in the accommodation industry. Using these types of sampling helped getting access to the needed population for an interview. Owner-managers of accommodations with fewer than 50 rooms, which in the Netherlands' make up more than $90 \%$ of the market [12], either independent or franchise, were selected. Interviews continued until saturation was reached. In total, 17 interviews were collected. Of those, just over half were with women. Most of the respondents were middle aged. Typically, the accommodations were Bed \& Breakfasts or small hotels with a restaurant. In this sample, the number of rooms to let ranged from 2 to 41 rooms, showing a spread amongst the size categories.

The interviews were transcribed true verbatim with the help of research assistants under the supervision of the main author. Standard confidentiality practices were adhered to. The data was analysed using a deductive approach. To avoid interviewer bias, coding and analysis of the transcripts was done by two researchers separate from each other. This process of triangulation increases the validity of the research outcomes by avoiding conceptual interpretation. Using an iterative process following DeCuir-Gunby et al. [29], a codebook was created based on data-driven open and axial coding of the interview transcripts. 
Intercoder reliability was tested by two researchers using the agreed upon codebook to code two randomly selected interview, and compare results. The Kappa coefficient showed almost perfect agreement.

\section{FINDINGS}

Below the findings from the data are presented following the three main themes deriving from the interviews, namely motives, sustainability and values.

\subsection{Motives}

Entrepreneurs enter into business due to different motives. A range of motives was found in the data, but in general two categories can be identified. The first contains those entrepreneurs with a passion for the accommodation industry, seeking a professional career in it. The second category contains entrepreneurs who have a passion for something else. This "something else" leads to a plethora of reasons to enter into business. Here one finds the lifestyle entrepreneurs that seek to balance their personal interests, needs of their family and their business career [18], [30], [31], the opportunity-driven entrepreneurs that faced some business opportunity and choose to become an accommodation entrepreneur because of it [32] and those for whom the accommodation is a means to fulfilling another main business goal. Though there might be an overlap between these reasons for going into the accommodation business, the entrepreneurs belonging to this category did not have owning-managing an accommodation as their primary goal. Therefore, this author calls entrepreneurs in this category "accidental hoteliers", which doesn't mean the accommodation form cannot be a B\&B.

In the category with accommodation entrepreneurs with a passion for the industry mostly owner-managers of hotels with a restaurant are found (I9, I10, I14 and I17), though there is one hotel without a restaurant (I15) and one B\&B (I6). When asked for their motives to enter into business, several interviewees mentioned that their parents owned a hotel, and they therefore grew up being and working in a hotel (I10, I14 and I17). One was even the 5th generation of hotel owners in his family (I17). Working in a hotel was therefore "taught from the nursery" (I10). Interestingly, over half of these entrepreneurs did venture into other lines of work before committing to a career as the owner-manager of an accommodation (I9, I14 and I17). As one person says "the hospitality sort of is an addiction" and that it had been "a little girl's dream" to own a hotel (I9). Others (I10 and I15) never left the hotel industry and went straight from a hospitality education into working in their hotel (I10), or had had a long career as general manager in hotels and were looking for a new challenge which they found in owning their own hotel (I15). Smaller types of accommodation owners may also fit in this category. For example, when moving to another part of the country, one B\&B owner-manager purposely looked for a house that gave them the possibility to operate a B\&B from it, with enough space to share with guest. Before actually purchasing the property, they looked into the possibility of getting the required licenses (I6). Similar findings were reported by Lashley and Rowson who found that accommodation owner-managers reported having a life-long dream of owning a hotel, or thought that they would enjoy operating one [18].

In the category with a passion for something else, the accidental hoteliers, most entrepreneurs are owner-mangers of an accommodation in support of another primary goal. Frequently, this other goal is having a restaurant (I7, I8, I13 and I16). As one interviewee stated "I had the ambition to own a restaurant, and coincidentally this one came with a hotel" (I7). Others said they were looking for a new challenge after owning a previous restaurant (I13). Though the accommodation was not their primary goal, these entrepreneurs did see the 
merit of it being connected to their restaurant. The guests that stay in the hotel, also eat in the restaurant (I7, I16). One entrepreneur referred to it helping him get through the low season of the restaurant, as it allowed him to sell package deals (I16).

For others, the main motivation is not found within the hospitality or related business. Amongst the accommodation owner-managers livestock and poultry farmers are found (I2 and I5). The poultry farmer wanted to build new stables, and bought land from her neighbours as to be able to do so (I2). Since the land purchased had a "perfectly good house" on it, they decided to "do something with it, as leaving it empty would be a waste" (I2). For the livestock farmer operating the B\&B was the result of his search for a way to supplement the income from his farm, thus keeping this primary business viable for the future (I5).

One interviewee said that he planned on becoming an entrepreneur, as he didn't want to work for a boss for long. However, "it didn't have to be in the hospitality industry" (I12) and he even didn't want to remain working in it for too long. However, when the previous owner of his hotel quit, this opportunity was offered to him, and he thought it would be nice. Another emerging motive for becoming an accommodation owner-manager is maybe the purest form of "accidental hotelier". These individuals didn't plan to go into the accommodation industry or even the hospitality industry. They simply had space available in their homes (I1, I3, I4). It came to be organically, out of the desire to remain living in their house after a divorce, or avoiding having a gap in their resume while being a stay-at-home-mom.

Lifestyle reasons for becoming an entrepreneur are found in both the passion for the accommodation industry, and the passion for something else category. Some female owner-managers mentioned that becoming an accommodation entrepreneur allowed them to work from home, which combined well with a family with (young) children (I1, I4 and I9). Spending quality time with family and friends is recognized as one of the lifestyle motives [30], [32]. Another commonality is not necessarily looking for profit maximization, but rather for alignment between one's personal interests and their business career [19], [30]. Few of these accommodation owner-managers were actively looking for expansion possibilities. As one entrepreneur states, "right now it is enjoyable and it is not an obligation" (I2). Expanding would mean having to hire personnel, whereas now she could manage on her own. Not aiming to maximize economic gain is recognized in tourism and hospitality literature as fitting with lifestyle reasons for operating a small business [3], [30]. On the other hand, some owner-managers did want to expand and are on the path of doing so. As one would expect based on literature [4], none of the entrepreneurs mentioned sustainability as the main reason for becoming an entrepreneur.

\subsection{Sustainability}

When asked to explain what sustainability means, most respondents state that it is about caring for the environment and not wasting its resources (I2, I3, I5, I8, I9, I10, I17), or preventing global warming (I10). Some individuals mention it is about durability, considering what it better for the environment for the future (I8, I9, I13). Several owner-managers sum up measures that are good for the environment and why they are good for the environment, rather than explaining what sustainability entails (I1, I3, I4, I6), where some referred to considering the impact of ones actions (I1, I5, I14) and "minimizing your footprint" (I14). Interestingly, only one entrepreneur specifically mentions social sustainability when discussing sustainability in his company (I8) where in his case it concerned the wellbeing of his employees. Another entrepreneur refers to the importance of sustainable relationships "with employees, guests and suppliers" (I17). Several entrepreneurs undertake measures that add value to the people aspect of sustainability, but do not recognize it as such. A typical example is sourcing products locally which they see 
as better for the environment due to less transport, but do not realize the social side of it. This situation found by the author is not exceptional, as in hospitality, but also in general, most initiatives are geared towards the environmental side of sustainability [33]. As pointed out by Elkington and Rowlands especially the value addition to the social dimension has been overlooked [34], and still many businesses focus on the environmental and economic dimensions only [33].

Though not necessarily indicative of a negative propensity towards sustainability, some entrepreneurs stated that they dislike the word sustainability (I2, I8, I11, I17). These interviewees feel the word is used as an umbrella term for many different actions, is "used too much" (I8) and that it is a "relative concept" (I11) used with a broad meaning (I17). Alcott states that sustainability is "one of the least meaningful and most overused words in the English language" [35, p. 246], and the author of this paper is confident that the same goes for the usage of the Dutch version of the word in the Netherlands.

The nature of providing hospitality is strongly connected to the pampering and comfort of the guest. When sustainability reduces such comfort, it is seen as conflicting with the nature of the entrepreneurs' business (I1, I7, I8, I9, I11). This puts entrepreneurs in a position where they have to consider which they will prioritize; being environmentally friendly or providing the guests with the pampering they expect [36]. Common issues described are having to maintain a comfortable temperature in the accommodation and the pertaining restaurant (I7, I9), as well as daily clean towels and bed sheets (I7, I9). Most of the entrepreneurs prioritized the comfort of the guest above reducing the use of natural resources, though one owner-manager stated that she refused to tumble dry the towels, as she though it to be unsustainable (I1).

Entrepreneurs state that when faced with a decision, they do consider if it is possible to choose a (more) sustainable option. They evaluate the cost and benefit of doing so, and then make an informed decision. This goes for basic measures such as replacing the LED lights, but also for more complex ones such as insolation. Typically, the occasion for evaluating the more complex measures is at the time of a planned refurbishment or new construction (I1, I3, I8, I9, I10, I14). One interviewee explains that they are currently renovating their hotel rooms, and are looking at if it can be done sustainable, and how (I14). Another mentions that they will renovate their kitchen, and in anticipation future law prohibiting the use of gas, will choose another form of cooking (I8). This coincides with literature, where this same moment was indicated as an opportune one for installing fixtures that helped the hotel reduce their utility usage [37]. Besides the added value to the environment when the business is updated according to sustainability standards, entrepreneurs state it is also about "keeping with the times", as well as keeping your company viable for potential future sale (I2, I17) At least the latter is an economic motive as well.

In general, cost is mentioned as typical barrier for not choosing the sustainable option, as well as it costing too much time and effort to implement (I1, I2, I10, I12, I14). As one entrepreneur states "sustainability clashes with reality" (I1), as it would cost her too much time and money to operate her accommodation fully sustainable. Literature shows that time and money constraints are commonly named as barriers to more thorough implementation [37].

The CSR measures implemented in the accommodations typically are what is referred to as "low-hanging fruit"; measures that require little investment and effort, and easily earn themselves back moneywise [39]. One can think of utility usage reducing measures such as LED lights (I5, I6, I7, I8, I9, I10) and water reducing taps (I10). Other measures oft used are related to the prevention and reduction of waste, mostly food waste. For example, to have less food waste from breakfast, some ask the guest beforehand how much and what they wish 
for breakfast (I4 + I7). These are environmental measure found to be carried out often by hoteliers [36]. Others try to reduce the waste by eating leftovers themselves, or giving it as food for chickens (I1, I2). Arguably, the latter may be because of frugality, rather than sustainability, as it is "sinful to waste" (I2). This perfectly fits what Tzschenke et al. "inherited thriftiness" [36, p. 131]. Others stated that sometimes they had to waste "good food" due to hygiene regulations (I9, I15), or that they chose mono-packs as they believed that even though it used plastic, it prevented food waste (I1, I15). A more radical food waste prevention technique was used by one entrepreneur who refused to serve food in buffet form, as it led to too much food being thrown away (I17).

\subsection{Values}

Entrepreneurs were asked to select their top 5 values from a set of 17 value cards both for themselves personally, as for themselves as entrepreneur. From the 17 interviewed owner-managers nine persons created a value top 5 of most important values that was different for themselves personally and themselves as an entrepreneur. There are instances where respondents justify this difference by stating that as an entrepreneur, they have more obligations. They need to be more ambitious and focus on keeping the company financially healthy, as they "have bills to pay" (I7). Morrison and Teixeira [31] state that the economic survival and viability of the company is an important topic for these smaller (lifestyle) businesses. Eight persons indicated that they are the same person as an individual as an entrepreneur, and that their top 5 values is thus the same. As one entrepreneur states "what you see is what you get" (11).

From Tables 1 and 2 below, it can be seen that the personal values most often mentioned are pleasure, freedom and enjoying life. Pleasure and enjoying life are hedonic, whereas freedom falls under a gain goal frame. Looking at the personal values which score highest, it can be seen that freedom, pleasure and enjoying life are the most prominent. Even if one takes the subtotal of all biospheric items, it still doesn't become one of the most prominent self-reported values for individuals. Looking at the entrepreneur values, the items most often mentioned are freedom, pleasure and ambitious, with freedom scoring highest of the values, followed by enjoying life and pleasure. Enjoying life and pleasure are hedonic, and freedom is gain.

Table 1: Personal value top 5.

\begin{tabular}{|l|c|c|}
\hline \multicolumn{3}{|c|}{ Personal value top 5 } \\
\hline Personal value & Score & Count \\
\hline Freedom & 54 & 14 \\
\hline Pleasure & 45 & 15 \\
\hline Enjoying life & 43 & 12 \\
\hline Ambitious & 24 & 9 \\
\hline Helpfulness & 20 & 7 \\
\hline & & \\
\hline Sub-total egoistic & 173 & 54 \\
\hline Sub-total altruistic & 47 & 17 \\
\hline Sub-total biospheric & 36 & 14 \\
\hline
\end{tabular}


Table 2: Entrepreneur value top 5.

\begin{tabular}{|l|c|c|}
\hline \multicolumn{3}{|c|}{ Entrepreneur value top 5 } \\
\hline Entrepreneur value & Score & Count \\
\hline Freedom & 58 & 14 \\
\hline Enjoying life & 36 & 10 \\
\hline Pleasure & 33 & 13 \\
\hline Ambitious & 31 & 11 \\
\hline Unity with nature & 25 & 8 \\
\hline & & \\
\hline Sub-total egoistic & 178 & 57 \\
\hline Sub-total altruistic & 37 & 14 \\
\hline Sub-total biospheric & 40 & 14 \\
\hline
\end{tabular}

Comparing the two tables to each other, one can see that there is not a large difference between the ranking of the values according to personal or entrepreneur top five. Part of this may be understood as almost half of the sample saying they are the same person as an individual and as an entrepreneur. The biospheric value items score slightly higher with the entrepreneurial values. This might be explained because in tourism (under which hospitality and thus accommodation falls) nature is oft part of the product sold. What stands out from the explanation of the values by the respondent, be it for themselves personally, or for themselves as entrepreneur, is that most of them do not distinguish between the items that fall in the biospheric category. Even though the definitions of the terms were in the back, when picking one of the biospheric items the explanation of it overlaps with the meaning of the other items. In several interviews the respondent even said that to them these items were the same, or so closely related to each other that they found it hard to choose just one (I5, I14). If all the items in the biospheric category are taken together, they would move to position 4 in the personal values ranking, and even position 2 in the entrepreneur values ranking. The table further supports the claim that at least in this sample group, most owner-managers are not what is considered a sustainable entrepreneur, but rather entrepreneurs who undertake CSR measures in their accommodations to a varying degree. The entrepreneurs are typically motivated by self-enhancement values, though some self-transcendent values are of importance.

When combining motives, sustainability and values, profiles of the different entrepreneurs can be created. For space reasons, the author will present one entrepreneur who, compared to others in the sample, reported having implemented more CSR measures in his accommodation and one entrepreneur who reported fewer CSR measures implemented.

One of the interviewees reporting more, and more stringent CSR measures implemented in his accommodation is a 64-year old male hotel-restaurant owner-manager, falling in the passion for the industry category (I17). He is a 5th generation hotel owner, and it is a lifestyle he was used to from at home. He chose to become an owner-manager as it would give him more independence and freedom. He feels sustainability is a very broad concept, but to him it meant minimizing one's impact on the environment, and thinking about continuity. The measures undertaken by him are especially strong on the social dimension of sustainability; he offers his employees fixed contracts rather than temporary ones, he has used the same suppliers for his company since starting, and offers many vegetarian and 
vegan menu options. Furthermore, he is Green Key certified (highest level), avoids waste as much as possible by e.g. not offering buffets in the restaurant, uses local, sustainable, and/or fair-trade products as much as possible and renewable energy. His personal values are the same as those as an entrepreneur. In his top 5 he lists social justice (2nd place), equality (3rd place) and preventing pollution (5th place).

Not all accommodation entrepreneurs reported having implemented as many or high effort measures as the one described above. One entrepreneur with fewer CSR measures reported is presented here below.

This interviewee reporting fewer sustainability measures implemented than others in this research sample is a 43-year old female owner-manager of a hotel-restaurant who falls in the passion for the industry category (I9). She always wanted to own a hotel, and when moving within the country used that opportunity to realize her dream. She also appreciated the possibility of having a family with working from home. She defines sustainability as thinking about earth in the long term and not wasting things. Sustainability measures reported in her hotel are switching of lights when they are not needed, lowering the heating when possible, and installing LED lights. When part of her hotel was renovated, roof insulation was put in. She states herself that the sustainability measures she implements are out of cost saving, and that she evaluates possible measures using that as a criterion. She stated that the guest's expectations of luxury and the hotel building being very old are barriers to becoming more sustainable. She lists her personal values and entrepreneurial values to be different, both consist of self-enhancement values except for "helpfulness". This helpfulness value is stated by several interviewees to be part of the hospitality DNA, and needed to work in this industry.

Of course, there are many nuances in between the two ends of spectrum presented here. To exemplify; one 32-year old male entrepreneur with a passion for something else does focus on the wellbeing of his employees, and using local seasonal ingredients, but hasn't implemented many other more stringent CSR measures in his business.

\section{CONCLUSIONS AND IMPLICATIONS}

This paper reported on the motives and values of micro and small sized accommodation owner-managers to enter into (sustainable) entrepreneurship. Combining the motives for entering into the hospitality industry, their definition of sustainability and the measures implemented by them with their dominant individual and entrepreneurial values is a new avenue of research in this field. Though the sample size for this study limits the ability to make firm conclusions, it does give interesting insights deepening the knowledge in this field of research, and opens paths for further research.

The results of this research indicate that the reasons for entering into the accommodation industry is not just out of passion for it, or lifestyle reasons, but also by chance. This group of entrepreneurs was labelled as "accidental hoteliers". Notwithstanding, entrepreneurs in either category can fall on the higher or lower end of the spectrum when looking at number and type of CSR measures implemented in their accommodation.

When asking the interviewees to define sustainability several entrepreneurs sum up CSR measures that are or could be taken in their business, rather than giving an actual meaning of it. Furthermore, almost all respondents refer to the environmental side of sustainability, and do not recognize the social dimension as being part of it. Some of these entrepreneurs even undertook several measures which add value to the social side of sustainability, but it doesn't occur to them to mention these when either giving the definition, or explaining the measures undertaken by them.

When looking at values, the card game as used in this research is an innovative manner to understand the respondent's dominant values based on 16 values established to be significant 
for pro-environmental behaviour +1 value from entrepreneurship theory, and used in questionnaire form. Overall, freedom, enjoying life and pleasure, all three self-enhancement values, rank highest in both the personal values, as well as the entrepreneurial values. When looking at the top 5 values listed of accommodation owner-managers with more and/or higher altruistic and biospheric values, we can recognize that these individuals also implement more and higher-effort sustainability measures in their business than others in this sample. Within the altruistic values, helpfulness and equality rank high. The helpfulness is seen as a trade needed when working in the hospitality industry, and equality was explained as having little power distance between themselves and their employees. Respondents found it hard to distinguish between the different biospheric values, and mostly explained them to belong to each other.

Though previous research has been carried out connecting reasons for entering the tourism industry to type and amount of sustainability measures implemented, this has not been connected to the persons' dominant values. This research implies that entrepreneurs listing more self-transcendent values in their top 5 personal and/or entrepreneurial values, also exhibited more and higher-effort sustainability measures implemented, and individuals with dominant self-enhancement values to have implemented fewer. Further (quantitative) research could prove the strength of this relation.

\section{REFERENCES}

[1] Walle, A.H., Business ethics and tourism: From micro to macro perspectives. Tourism Management, 16(4), pp. 263-268, 1995.

[2] Steg, L., Values, norms, and intrinsic motivation to act proenvironmentally. Annual Review of Environment and Resources, 41, pp. 277-292, 2016.

[3] Ateljevic, I. \& Doorne, S., "Staying within the fence": Lifestyle entrepreneurship in tourism. Journal of Sustainable Tourism, 8(5), pp. 378-392, 2000.

[4] Font, X., Garay, L. \& Jones, S., Sustainability motivations and practices in small tourism enterprises in European protected areas. Journal of Cleaner production, 137, pp. 1439-1448, 2016.

[5] Thomas, R., Shaw, G. \& Page, S.J., Understanding small firms in tourism: A perspective on research trends and challenges. Tourism Management, 32(5), pp. 963976, 2011.

[6] UN, Goal 12: Ensure sustainable consumption and production patterns, n.d. www.un.org/sustainabledevelopment/sustainable-consumption-production/.

[7] Cohen, B. \& Winn, M.I., Market imperfections, opportunity and sustainable entrepreneurship. Journal of Business Venturing, 22(1), pp. 29-49, 2007.

[8] Schaltegger, S. \& Wagner, M., Sustainable entrepreneurship and sustainability innovation: categories and interactions. Business Strategy and the Environment, 20(4), pp. 222-237, 2011.

[9] World Travel \& Tourism Council, Evaluation of job creation in G20 countries through maximising infrastructure capacity through technology that facilitates travel and integrates security, 2018.

[10] UNWTO, European Union tourism trends. UNWTO: Madrid, 2018.

[11] OECD, OECD Tourism trends and policies 2020. OECD, 2020.

[12] CBS Statline, Bedrijven; naar economische activiteit (SBI 2008, 2006-2010), 2012.

[13] UNWTO (United Nations World Tourism Organization), From Davos to Copenhagen and beyond: advancing tourism's response to climate change. UNWTO, 2009.

[14] MVO Nederland, Nut en noodzaak, 2015. http://mvonederland.nl/sector/toerisme. Accessed on: 11 Dec. 2015. 
[15] Sloan, P., Legrand, W. \& Chen, J.S., Sustainability in the Hospitality Industry, Butterworth-Heinemann: Boston, MA, 2009.

[16] Garay, L. \& Font, X., Doing good to do well? Corporate social responsibility reasons, practices and impacts in small and medium accommodation enterprises. International Journal of Hospitality Management, 31(2), pp. 329-337, 2012.

[17] Ahmad, S.Z., Entrepreneurship in the small and medium-sized hotel sector. Current Issues in Tourism, 18(4), pp. 328-349, 2015.

[18] Lashley, C. \& Rowson, B., Lifestyle businesses: Insights into Blackpool's hotel sector. International Journal of Hospitality Management, 29(3), pp. 511-519, 2010.

[19] Fotiadis, A.K., Vassiliadis, C.A. \& Rekleitis, P.D., Constraints and benefits of sustainable development: A case study based on the perceptions of small-hotel entrepreneurs in Greece. Anatolia, 24(2), pp. 144-161, 2013.

[20] Drucker, P., Innovation and Entrepreneurship: Principles and Practices, HarperTrade: New York, 1985.

[21] Schwartz, S.H., Universals in the content and structure of values: Theoretical advances and empirical tests in 20 countries. Advances in Experimental Social Psychology, 25(1), pp. 1-65, 1992.

[22] Schumpeter, J.A., The theory of economic development, translated by Redvers Opie. Harvard: Economic Studies, 46, pp. 1600-0404, 1934.

[23] Skokic, V. \& Morrison, A., Conceptions of tourism lifestyle entrepreneurship: Transition economy context. Tourism Planning \& Development, 8(2), pp. 157-169, 2011.

[24] Dewhurst, P. \& Horobin, H., Small business owners. The Management of Small Tourism and Hospitality Firms, pp. 19-38, 1998.

[25] Tomassini, L., The co-creation of diverse values and paradigms in small values-based tourism firms. Tourism Recreation Research, 44(3), pp. 359-369, 2019.

[26] Sarasvathy, S.D., Causation and effectuation: Toward a theoretical shift from economic inevitability to entrepreneurial contingency. Academy of Management Review, 26(2), pp. 243-263, 2001.

[27] Steg, L., Bolderdijk, J.W., Keizer, K. \& Perlaviciute, G., An integrated framework for encouraging pro-environmental behaviour: The role of values, situational factors and goals. Journal of Environmental Psychology, 38, pp. 104-115, 2014.

[28] Teng, Y.M., Wu, K.S. \& Liu, H.H., Integrating altruism and the theory of planned behavior to predict patronage intention of a green hotel. Journal of Hospitality \& Tourism Research, 39(3), pp. 299-315, 2015.

[29] DeCuir-Gunby, J.T., Marshall, P.L. \& McCulloch, A.W., Developing and using a codebook for the analysis of interview data: An example from a professional development research project. Field Methods, 23(2), pp. 136-155, 2011.

[30] Marcketti, S.B., Niehm, L.S. \& Fuloria, R., An exploratory study of lifestyle entrepreneurship and its relationship to life quality. Family and Consumer Sciences Research Journal, 34(3), pp. 241-259, 2006.

[31] Morrison, A. \& Teixeira, R., Small business performance: a tourism sector focus. Journal of Small Business and Enterprise Development, 2004.

[32] Williams, C.C., The motives of off-the-books entrepreneurs: necessity-or opportunitydriven? International Entrepreneurship and Management Journal, 5(2), p. 203, 2009.

[33] Melissen, F., Cavagnaro, E., Damen, M. \& Düweke, A., Is the hotel industry prepared to face the challenge of sustainable development?. Journal of Vacation Marketing, 22(3), pp. 227-238, 2016. 
[34] Elkington, J. \& Rowlands, I.H., Cannibals with forks: the triple bottom line of 21 st century business. Alternatives Journal, 25(4), p. 42, 1999.

[35] Alcott, B., Review: The conundrum: How scientific innovation, increased efficiency, and good intentions can make our energy and climate problems worse, David Owen, Riverhead Books, New York (2011), ISBN: 978-1-59448-561-9, 2013.

[36] Tzschentke, N.A., Kirk, D. \& Lynch, P.A., Going green: Decisional factors in small hospitality operations. International Journal of Hospitality Management, 27(1), pp. 126-133, 2008.

[37] Bohdanowicz, P., Environmental awareness and initiatives in the Swedish and Polish hotel industries - survey results. International Journal of Hospitality Management, 25(4), pp. 662-682, 2006.

[38] Lepoutre, J. \& Heene, A., Investigating the impact of firm size on small business social responsibility: A critical review. Journal of Business Ethics, 67(3), pp. 257-273, 2006.

[39] Klewitz, J. \& Hansen, E.G., Sustainability-oriented innovation of SMEs: a systematic review. Journal of Cleaner Production, 65, pp. 57-75, 2014. 